\title{
Do Biology Majors Really Differ from Non-STEM Majors?
}

\author{
Sehoya Cotner, ${ }^{*}$ Seth Thompson, and Robin Wright \\ Department of Biology Teaching and Learning, College of Biological Sciences, University of \\ Minnesota, Minneapolis, MN 55455
}

\begin{abstract}
Recent calls to action urge sweeping reform in science education, advocating for improved learning for all students-including those majoring in fields beyond the sciences. However, little work has been done to characterize the differences-if any exist-between students planning a career in science and those studying other disciplines. We describe an attempt to clarify, in broad terms, how non-STEM (science, technology, engineering, and mathematics) majors differ from life sciences majors, and how they are similar. Using survey responses and institutional data, we find that non-STEM majors are not unilaterally science averse; non-STEM majors are more likely than biology majors to hold misconceptions about the nature of science, yet they are not completely ignorant of how science works; non-STEM majors are less likely than biology majors to see science as personally relevant; and non-STEM majors populations are likely to be more diverse-with respect to incoming knowledge, perceptions, backgrounds, and skills-than a biology majors population. We encourage science educators to consider these characteristics when designing curricula for future scientists or simply for a well-informed citizenry.
\end{abstract}

\section{INTRODUCTION}

Recent calls to action urge sweeping reform in science education, advocating for improved learning for all students (American Association for the Advancement of Science [AAAS], 2011). A growing body of literature illustrates that active-learning techniques and an inquiry-based curriculum improve learning, further compelling educators to institute these practices (Luckie et al., 2004, 2012; Prince, 2004; Walker et al., 2008; Armbruster et al., 2009; Haak et al., 2011; Cotner et al., 2013; Guang and Bierma, 2013; Freeman et al., 2014; Connell et al., 2016). Yet, as instructors migrate to evidence-based teaching, they invariably make assumptions about their students' characteristics-including science identity, confidence, motivation, incoming knowledge and ability, and the potential to learn.

To confirm or reject these assumptions about our students, we can look to recent work that draws connections between student characteristics, perceptions of science and scientists, and scientific knowledge. For example, there is a small but significant correlation between general scientific knowledge and attitudes (confidence, interest) toward science, a relationship that spans continents and cultures. Specifically, confidence plays a vital part in persistence, retention, and abilities in STEM (science, technology, engineering, and mathematics) subjects (Lundeberg et al., 1992), and confidence differences are related to differences in students' motivation (Fenollar et al., 2007). Science confidence may also be affected by factors such as in-class engagement, intrinsic motivation, self-regulatory skills, gender, experience, and test anxiety (Pintrich et al., 1991; Eccles et al., 1993; Pajares, 1996; Cotner et al., 2011; Nissen, 2016). However, if there is a causal basis for the correlation between confidence and knowledge, it has not been established (Allum et al., 2008). Similarly, increases in attitudes toward science have been correlated with increases in knowledge (Cook and Mulvihill, 2008); again, these correlations have not been disentangled to reveal possible causation.
Peggy Brickman, Monitoring Editor Submitted November 28, 2016; Revised April 14, 2017; Accepted April 17, 2017

CBE Life Sci Educ September 1, 2017 16:ar48

DOI:10.1187/cbe.16-11-0329

*Address correspondence to: Sehoya Cotner (sehoya@umn.edu)

(c) 2017 S. Cotner et al. CBE-Life Sciences Education () 2017 The American Society for Cell Biology. This article is distributed by The American Society for Cell Biology under license from the author(s). It is available to the public under an Attribution-Noncommercial-Share Alike 3.0 Unported Creative Commons License (http:// creativecommons.org/licenses/by-nc-sa/3.0) "ASCB®" and "The American Society for Cell Biology ${ }^{\circledR}$ " are registered trademarks of The American Society for Cell Biology. 
Student characteristics can have a profound influence on how students perceive and learn science. Recent work on identity-protective cognition (Kahan, 2010, 2012, 2013) demonstrates that culture and a sense of in-group identity can impact not only perceptions of science and scientists but also how an individual responds to politically polarizing scientific information. For example, an individual who identifies as a conservative male (vs. his liberal female counterpart) is less likely, as a function of increased knowledge, to accept the science of climate change (McCright and Dunlap, 2011). Similarly, religious affiliation can preclude acceptance of evolution-especially human evolution-even in response to repeated evidentiary claims (Cotner et al., 2010; Moore et al., 2011; Rissler et al., 2014).

Furthermore, scientific knowledge is socially and personally relevant. Ignorance of science (both from a factual and procedural standpoint) has implications for policy (Ding et al., 2011), personal health choices (Kahan, 2013), and support for governmental funding of science research (Miller, 2004; Sanz-Menendez et al., 2014).

This information can be valuable as we develop our curricula or revise existing courses. However, much of the work thus far fails to inform a key dichotomy in many of our institutionsthat of the biology majors versus non-STEM majors audience. Specifically, how do students interested in life sciences careers (i.e., "biology majors") differ from those who are studying other fields (non-STEM majors)? Do we make the same assumptions about a biochemistry major as a marketing major? Does a future ecologist find relevance in the same problems as a future historian? Furthermore, if they differ, do we acknowledge these differences in our curricular design? If so, how? And how would curricular reform differentially impact biology majors and nonSTEM majors?

These topics have not been completely overlooked, as some investigators have established general differences between biology majors and nonmajors. For example, Smith et al. (2004) confirm many suspicions that the non-STEM majors enrolled in introductory science courses are there primarily to fulfill a requirement, not to quench some thirst for knowledge or better position themselves in the job market. Other investigators have documented empirical differences in non-STEM majors and biology majors with respect to motivation (Glynn et al., 2011), interest (Knight and Smith, 2010), understanding of the nature of science (Partin et al., 1998), and science content knowledge (Knight and Smith, 2010; Medina et al., 2014). Additionally, many (Hobson, 2001; Arwood, 2004; Kolb and Kolb, 2005; Cook and Mulvihill, 2008; Busch, 2010; Cotner and Gallup, 2011; Guang and Bierma, 2013) have demonstrated that an emphasis on the applications of scientific information-for example, via civic engagement, environmental issues, or public health-can have positive impacts on knowledge acquisition and attitudes toward science.

However, gaps in our understanding remain, especially in terms of characterizing our students as they enter our courses. Specifically, do non-STEM majors differ in terms of their science identity; confidence in their ability to do science; and perceptions of science, scientists, and scientific methodology? The work we describe in this paper reflects an attempt to clarify, in broad terms, how non-STEM majors differ from biology majors, how they are similar, and where we still need further information.
At our institution, students are admitted, as first-semester freshmen, into colleges with defined disciplines (e.g., College of Biological Sciences, College of Liberal Arts, College of Design) and a suite of corresponding majors (e.g., in the College of Biological Sciences, possible majors include biochemistry, neuroscience, and ecology, evolution, and behavior). This early grouping enabled us to tackle many of our questions about student identity, interest and confidence in doing science, and perceptions of scientists and scientific methods. Specifically, we had the following questions:

1. Are incoming biology majors different from non-STEM majors with respect to descriptive characteristics-gender, academic preparation, ethnicity, citizenship?

2. Do incoming biology majors exhibit stronger "science identity" than their non-STEM majors counterparts?

3. Are non-STEM majors less confident in their ability to do science than are incoming biology majors?

4. Do these two groups differ in their perceptions of scientists and scientific methods?

Our goal was to identify meaningful differences between our target populations to help us design curricula in ways that would benefit all students-developing biologists as well as those majoring in other fields.

\section{METHODS}

\section{Terminology}

We define "biology major" as any student entering the College of Biological Sciences (CBS) at the University of Minnesota. Any student in any of the university's other colleges (whether an entering freshman or not) is a "nonmajor." The nonmajors designation is complicated by the fact that there are three science-focused colleges at the university-CBS, the College of Science and Engineering (CSE, which does not have a life sciences emphasis), and the College of Food, Agriculture, and Natural Resources Sciences (CFANS, which does have a life sciences emphasis); however, the largest group of nonmajors are those in the College of Liberal Arts (CLA; further discussed in the Results section). Therefore, to provide clarity, we exclude the CSE and CFANS students from our analysis to compare developing biologists with students who do not plan to major in the sciences; we designate these the "non-STEM majors."

\section{Student Population}

Students include individuals enrolled in one of the following

- A prematriculation college orientation program (the Nature of Life), held off-site at the university's Itasca Biological Station and Laboratories. These students all plan to enter the CBS, having expressed the intention of studying biology and having gained admission to CBS. This group is hereafter referred to as the "biology majors" group.

- An introductory biology course designed for students enrolled in any of the university's colleges besides CBS. These students are primarily taking introductory biology to fulfill a graduation requirement ("natural sciences with laboratory"). Several options exist for those selecting such a course and range from a course focused on environmental problems and solutions to one emphasizing the evolution and biology of sex. 


\section{Data Collection}

Biology majors completed surveys in person before the official start of the Summer orientation program. Responses from nonSTEM majors were solicited via an email from a program administrator. Before the first day of class, students were introduced to the project and asked to complete an online survey developed to address the questions of several instructors and biology education researchers. The email assured students that survey participation was voluntary, and they were free to omit any or all items from consideration.

The survey items used in the described work targeted the respondent's science (as well as artistic, athletic, etc.) identity (Cole, 2012); confidence (via items drawn and, in some cases, modified from existing instruments; Lopatto, 2004; Seymour et al., 2004); and perceptions of science, scientists, and scientific processes (Lopatto, 2004; and some generated in-house); these survey items are available in the Supplemental Material. Most categories (e.g., "science confidence") are addressed by several items, with the exception of the single-item "science identity" metric (Cole, 2012). In this manner, we have narrowly defined science identity based on a student's reported affinity for feeling like a "science person, " a definition consistent with that of Gee (2000) and Carlone and Johnson's (2007) "recognition" component of identity (i.e., "I see myself as a scientist"). All items are part of a larger "core" survey administered to all students in introductory biology courses. The survey has been administered for several years and is used for both course evaluation and improvement and biology education research.

Students were encouraged to respond to the survey by the offer of one extra-credit point for survey completion, although students were assured that they could omit any of the items from the survey and still qualify for the extra credit. The extracredit benefit amounted to between $0.1 \%$ and $0.33 \%$ of one percentage point in the course overall, so its impact on a student's grade was negligible; however, we chose to use extra credit because of past experience suggesting that response rates increased more than fivefold with this small incentive. We also collected institutional information on each survey respondent's college, declared major, ACT score (as a measure of academic preparation), year in school, international status, gender, and ethnicity. Ethnicity data were combined into "white" and "nonwhite" to eliminate the possibility of identifying individual students. The University of Minnesota's Institutional Review Board evaluated the survey as exempt from review, along with survey administration, and the use of institutional data.

\section{Analysis}

A total of 1450 students completed the precourse surveys (524 biology majors and 926 nonmajors-of whom 662 were nonSTEM majors); given that a total of 2260 (538 biology majors and 1722 nonmajors) students were asked to complete surveys, this figure represents response rates of greater than $97 \%$ for biology majors and 54\% for nonmajors. Biology majors completed the surveys in person, before a required off-site, precollege orientation session, whereas nonmajors completed their surveys online during the first week of their introductory biology course. These different delivery methods likely explain the dramatically different response rates.

Survey items were all based on Likert-scale (either four-item or five-item) responses and were analyzed categorically (to compare the spread and strength of the responses). Categorical responses were compared via chi-square tests for deviations from the comparison group. Standard least-squares multiple regression was used to determine which additional characteristics (i.e., ACT, ethnicity, or gender) predicted survey responses; complete results of the multiple regression, by item, are included in the Supplemental Material. All statistical analyses were conducted using JMP Pro, version 12.0.1.

\section{RESULTS AND INTERPRETATION \\ Question 1. Are Incoming Biology Majors Different from Nonmajors with Respect to Descriptive Characteristics- Gender, Academic Preparation, Ethnicity, Citizenship?}

Institutional data (summarized in Table 1) indicate that nonSTEM majors are, in general, less female-dominated, more international, and exhibit greater diversity with respect to ethnicity than do biology majors. Also, because only incoming biology majors took the survey, the majority $(60 \%)$ of these students were classified as freshmen. Non-STEM majors included students from throughout the curriculum, and therefore had fewer (11\%) freshmen. Biology majors have higher ACT scores, on average, than do students from the university community at large. Given that CBS has become increasingly more selective over the past decade, it is not surprising that the biology majors consist of many honors students with high ACT scores. We are unsure why differences exist with respect to international status, but our observed ethnicity differences echo national trends indicating that STEM fields in general are characterized by disproportionately few members from non-white groups (National Academy of Science, National Academy of Engineering, and Institute of Medicine [NAS], 2011).

TABLE 1. General characteristics of respondents entering the CBS (biology majors) vs. those intending to major in non-science fields (non-STEM majors) with characteristics for the entire student body (excluding CBS students) also included for comparison

\begin{tabular}{|c|c|c|c|c|}
\hline & Majors & Nonmajors & Non-science majors & $\begin{array}{c}\text { University of Minnesota } \\
\text { student body }\end{array}$ \\
\hline Percent female & 64.4 & 58.5 & 60.6 & 50.1 \\
\hline Percent international & 1.9 & 8.6 & 9.5 & 10.6 \\
\hline Percent white & 75.7 & 71.2 & 70.2 & 69.1 \\
\hline Percent freshman & 59.9 & 10.4 & 10.7 & 16.9 \\
\hline Median ACT score & 30 & 27 & 27 & $28^{\mathrm{a}}$ \\
\hline
\end{tabular}

aStudent body ACT average includes CBS students, as it was not possible to disaggregate the institutional data. 
Ethnicity (NAS, 2011; National Science Foundation, National Center for Science and Engineering Statistics [NSF, NCES], 2015), gender (NSF, NCES, 2015; Nissen and Shemwell, 2016; Wilson et al., 2016), and ACT (Noble and Sawyer, 2002; Alarcon and Edwards, 2012) have all been associated with science performance and self-efficacy, and each of these variables was associated with several of our reported outcomes, in addition to whether a student was a biology major or not. Standard least-squares multiple regression to detect the effect sizes of each of these variables revealed that ACT and gender are significant predictors of most responses, along with majors classification (Supplemental Material). For example, ACT, gender, and student classification all predict confidence in a student's ability to "understand and evaluate scientific literature" and "analyze a set of observations, tables, or graphs." For some items, ethnicity was also a significant response predictor: for example, ethnicity predicted student agreement with the statement "I can do well in science courses." Year in school was not a significant predictor of any of our outcomes. These findings confirm that many factors influence our students' motivation and capacity to "do" science-not merely whether one has declared an intent to major in science.

\section{Question 2. Do Incoming Biology Majors Exhibit Stron- ger "Science Identity" Than Their Non-STEM Majors Counterparts?}

Incoming biology majors are similar to non-STEM majors with respect to spiritual, athletic, and creative identities. However, biology majors were more likely to describe themselves as "a science person" ( $p<0.001)$, and non-STEM majors are slightly-but significantly-more likely to report an artistic identity ( $p<0.001$; see distribution of responses in Figure 1). In response to the prompt "How much does 'a science person' describe you?," $85.7 \%$ of biology majors responded with either

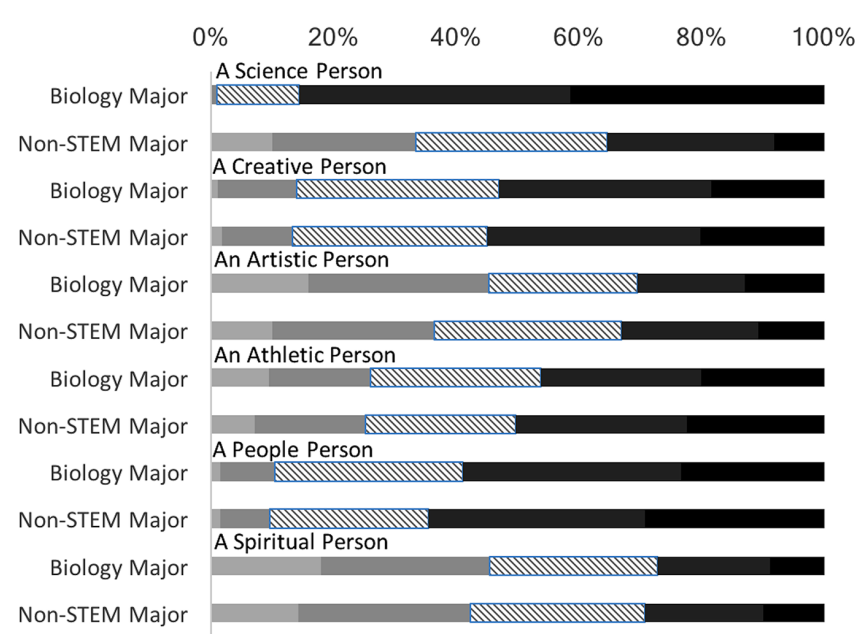

Not at all like me $\quad$ Not much like me $\mathbb{Q}$ Somewhat like me
Mostly like me $\quad$ Very much like me

FIGURE 1. Student responses to the "identity" items on the precourse survey. Biology majors express stronger "science identity" than their non-STEM majors counterparts, whereas nonSTEM majors had a slightly but significantly stronger artistic identity. There were no significant differences in any other identify grouping. "mostly like me" or "very much like me," compared with $35.3 \%$ for non-STEM majors on the same item.

Again, it is not surprising that students pursuing scientific studies in college are more likely to claim a science identity. These data are encouraging, given the importance of "fit"with the institution, discipline, and so on-in increased retention and success in college (Terenzini and Pascarella, 1980; Tinto, 1987; O'Keefe et al., 1993). But this trend also confirms any suspicion that, in general, our non-STEM majors do not see themselves as "science people." However, more than a third of the students in non-STEM majors did strongly align with a science identity, demonstrating a broad range in perspectives toward science. Admittedly, it is difficult to interpret single-item responses; we do not know how students interpret the phrase "a science person," and our best guide in this case is how students identify with other descriptors (creative, athletic, etc.; see the Supplemental Material and Figure 1). Future work should attempt to clarify what "a science person" means to studentsthose intending to major in science and otherwise.

\section{Question 3. Are Non-STEM Majors Less Confident in Their Ability to Do Science Than Are Incoming Biology Majors?} Non-STEM majors averaged lower, in their science confidence, on every related metric in our survey (Figures 2 and 3). For example, on the item, "I can understand and evaluate the science related to a current issue, such as climate change," $83.5 \%$

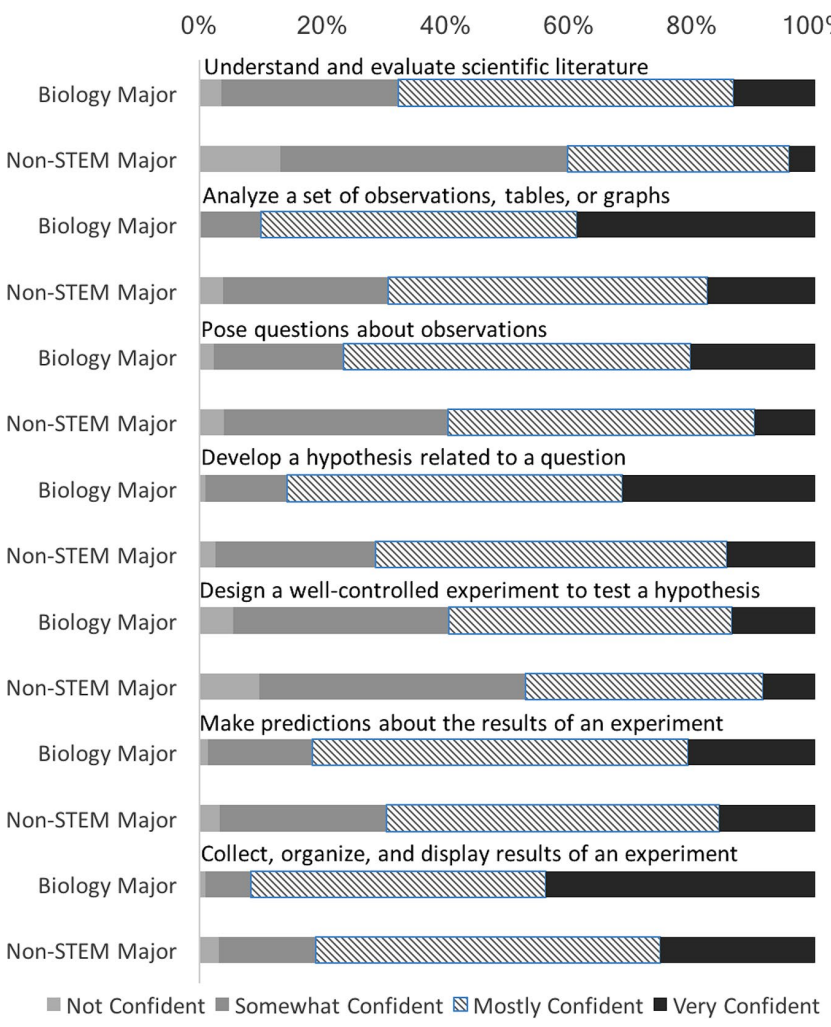

FIGURE 2. Percentage of respondents in each category on questions of science confidence, on a four-point scale (where $1=$ not confident and 4 = very confident), for biology majors and non-STEM majors (all differences significant when analyzed categorically via chi-square, $p<0.001$ ). 


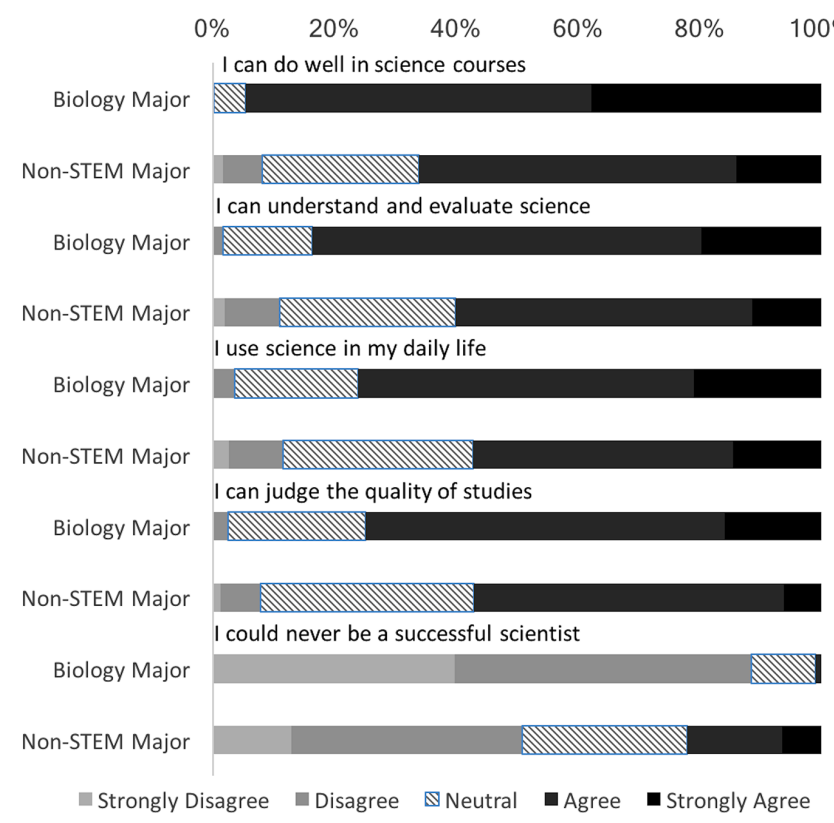

FIGURE 3. Percentage of respondents in each category on questions of science confidence, on a five-point scale (where 1 = strongly disagree and 5 = strongly agree), for biology majors and non-STEM majors (all differences significant when analyzed categorically via chi-square, $p<0.001$ ).

of biology majors either agreed or strongly agreed compared with $60.2 \%$ for non-STEM majors. On some items (e.g., "I can do well in science courses" or "I could never be a successful scientist"), the differences exceeded $20 \%$. However, the trends were similar across the groups; on no single item did biology majors completely agree or non-STEM majors completely disagree. On no single item were biology majors completely confident, while non-STEM majors lacked confidence outright. For example, non-STEM majors still tend to disagree with the statement "I could never be a successful scientist," and tend to agree with the statement "I can do well in science courses."

\section{Question 4. Do These Two Groups Differ in Their Perceptions of Scientists and Scientific Methods?}

Non-STEM majors are more likely to view science as a static, stand-alone domain, one that is mostly "an accumulation of facts, rules and formulas" (42\% of non-STEM students agree compared with $20 \%$ of biology majors) and "not connected to non-science fields such as history, literature, economics, or art" (7.6\% of non-STEM students agree compared with only $2.3 \%$ of biology majors; Figure 4). However, as with science confidence, the trends are similar between the groups. For example, all groups disagree, on average, with the statement "Science is not connected to non-science fields such as history, literature, economics, or art."

Non-STEM majors are also less likely to agree (84.9\% vs. $95.2 \%$ ) with the statement "Science is a process of gathering and interpreting evidence (for example, making observations to explain the natural world)." Similarly, non-STEM majors see science as less personally relevant ( $88.4 \%$ vs. $98 \%)$ than do biology majors, as measured by items such as "Science can be used in a person's daily life."

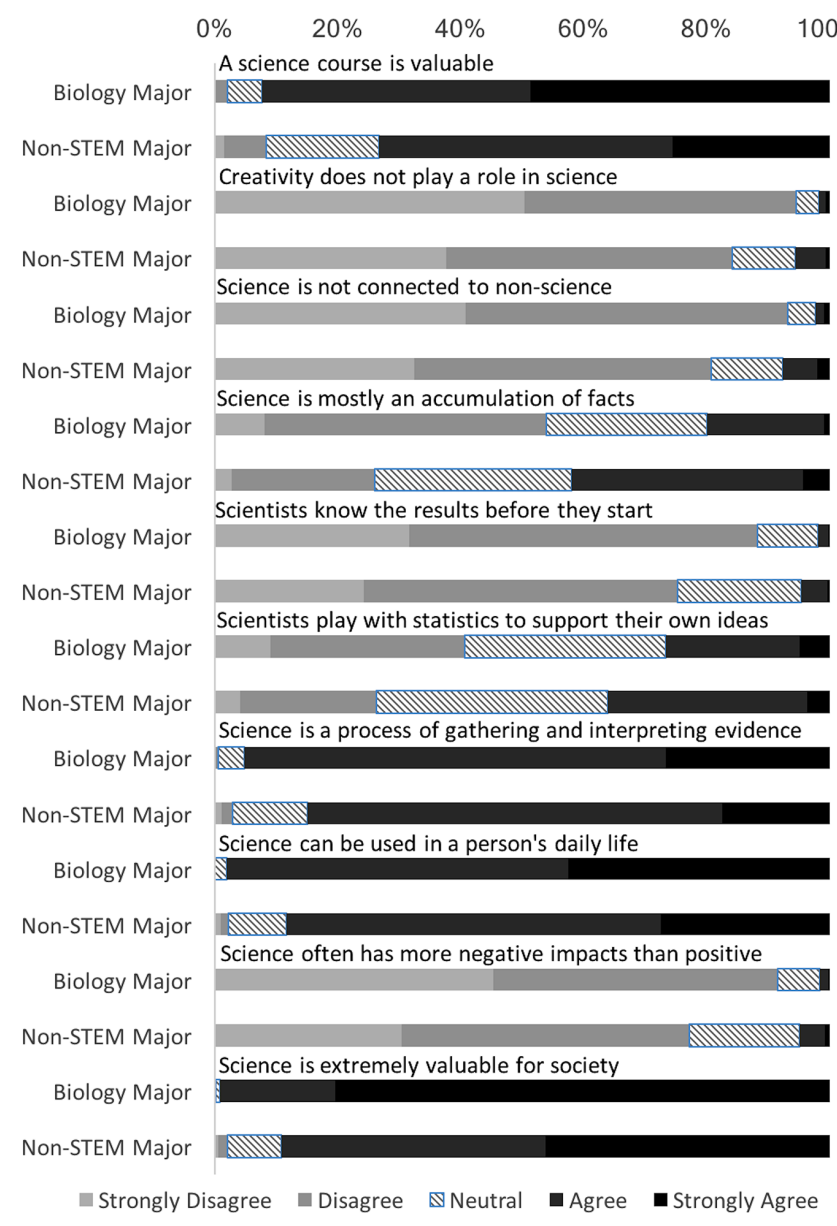

FIGURE 4. Percentage of respondents in each category on questions of perception of science, on a five-point scale (where $\mathbf{1}$ = strongly disagree and $\mathbf{5}=$ strongly agree), for biology majors and non-STEM majors (all differences significant when analyzed categorically via chi-square, $p<0.001$ ).

Finally, it is worth noting that, although the two groups differ significantly, non-STEM majors still agree on average with the statement "A science course is a valuable part of a complete undergraduate education, regardless of major." Non-STEM majors also agree with the statements "Science can be used in a person's daily life" and "Science is extremely valuable for society." These findings echo the general public's views on science as being largely valuable (Miller, 2004; Allum et al., 2008), and further challenge the idea that typical non-STEM majors are, in general, science averse.

\section{CONCLUSION}

Recent reports, such as the 2011 Vision and Change report, encourage reform that results in increased learning for all students (AAAS, 2011). However, much of the literature on evidence-based instruction in STEM is focused on developing scientists and fixing the holes in the "leaky STEM pipeline." We do not challenge the importance of this work, rather, our focus is on identifying characteristics of another important group of students-those who will not necessarily become scientists but who will use scientific information in their daily lives. 
Our findings are restricted to student characteristics at a single institution, and this constraint may limit our ability to generalize. However, it is logical to assume that any group that includes individuals pursuing a variety of disciplines is going to be more diverse than a group with a common pursuit. In addition, as we design curricula for specific audiences, we are confident that we can use information reported here to make some cautious assumptions about incoming student populations elsewhere. In a nutshell, nonmajors are less confident in their ability to do science, more likely to hold naïve conceptions about scientists and scientific methods, and less likely to see value in science. Also, although we report many areas of difference that are statistically significant, many of these differences may not be practically relevant. For example, non-STEM majors differ statistically from majors in the extent to which they agree with the statement "I think that science is extremely valuable for society," yet this $10 \%$ difference (Figure 4) is unlikely to translate into any meaningful differences in how we teach. However, the large differences in confidence (e.g., only $60.2 \%$ of non-STEM majors agree that they can "understand and evaluate the science related to a current issue," while $83.5 \%$ of biology majors agree with this statement; Figure 3) could inform practical aspects of our teaching. Knowing non-STEM majors are notably less confident about "doing" science, an instructor could scaffold class exercises into a series of steps-with the intent of building a student's confidence over time (e.g., using guided-inquiry techniques such as process-oriented guided-inquiry learning; Moog et al., 2006).

In sum, our nonmajors still have a tractable level of confidence in their ability to do science, have foundational knowledge of what science is and what scientists do, and see value in science. They also see value in taking a science course in college, regardless of their disciplinary goals. The latter point should be encouraging to educators who might reluctantly agree to teach science courses to nonmajors. The introductory course is likely the only opportunity to convey to nonmajors how science actually works, a fact that underscores the importance of knowing, and reaching these students.

It bears repeating that these incoming differences do not necessarily align with performance differences, an interpretation supported by some (Sundberg and Dini, 1993; Wright and Klymkowsky, 2005) and rejected by others (Knight and Smith, 2010), and one that warrants further study. Specifically, we need to tease out the relationship between attitude and knowledge to help us determine our teaching priorities-do we focus on attitudes to impact knowledge or vice versa? Finally, we are unable to conclude which, if any, of the responses we document are associated with salient gains in scientific skills, knowledge, or personal decision making.

Regardless of these notable shortcomings, we suggest these data as a starting point for crafting a broad understanding of our students and differentiating between our majors and nonmajors. In designing our curricula, we would be advised to realize, first, that our non-STEM majors students, like members of the general population, are not unilaterally science averse (Miller, 2004; Allum et al., 2008). However, certain politically polarizing topics (e.g., human evolution, anthropogenic climate change) might be viewed differently by nonmajors (Paz-y-Miño and Espinosa, 2009) and therefore should be approached with care (Miller et al., 2006; Kahan, 2010; McCright and Dunlap,
2011; Barnes and Brownell, 2016; Barnes et al., 2017). Fortunately, several recent works address the teaching of evolution (O'Brien et al., 2009; Abraham et al., 2012; Schauer et al., 2014; Gibson and Hoefnagels, 2015; Manwaring et al., 2015) and climate change (Cordero et al., 2008; McCaffrey and Buhr, 2009; Svihla and Linn, 2012) and can guide instructors in navigating these socially controversial topics. For example, Barnes et al. (2017) found that introducing students to practicing scientists who are themselves openly religious can alleviate student concerns about an incompatibility between evolutionary biology and religious convictions. Similarly, Manwaring et al. (2015) alleviated student concerns by directly addressing religious doctrine on the subject of evolution. Also, Kahan (2013) demonstrates how strategic word choice can serve to minimize an individual's defensiveness about topics such as evolution and climate change.

While it is true that our non-STEM majors are more likely than our biology majors to hold misconceptions about the nature of science, they are not completely ignorant of how science works. Thus, meaningful inquiry or even course-based research experiences may be as suitable for non-STEM majors as for biology majors, although allowances might be necessary for small discrepancies in understanding. Biology majors may be more likely to have engaged in, and have familiarity with, scientific practices (through summer camps, high-school electives, etc.); if that is the case, non-STEM majors may need additional assistance in articulating a testable question, designing a practical experiment, or any of the many skills that are involved in scientific inquiry. In fact, for many non-STEM majors, an introductory life sciences course may be their only opportunity to experience an authentic scientific experience. Further work is needed to determine how inquiry- and course-based research experiences influence scientific literacy.

Also, non-STEM majors are less likely than biology majors to see science as personally relevant. Whether this perception influences learning remains to be seen; however, several investigators have reported on the value of using personal examples in an applied context when teaching for general scientific literacy (Hobson, 2001; Arwood, 2004; Kolb and Kolb, 2005; Cook and Mulvihill, 2008; Busch, 2010; Cotner and Gallup, 2011; Guang and Bierma, 2013).

Finally, our non-STEM majors population is more diverse (with respect to country of origin, ACT scores, and ethnicity) than our biology majors population-a distinction that may or may not mirror the situation at other institutions. In designing curricula for all students from a diversity of backgrounds and holding a range of scientific viewpoints, educators can look to the literature documenting the value of active learning. Specifically, active-learning techniques have been associated with significant gains, and these techniques are especially noteworthy for increasing the performance of students from groups traditionally underrepresented in science (Haak et al., 2011; Allen-Ramdial and Campbell, 2014; Bangera and Brownell, 2014).

Designing curricula for a student population that is so diverse-with respect to incoming knowledge, perceptions, backgrounds, and skills-involves opportunities as well as challenges. However, we know that all of our students are members of a society that votes, makes personal health choices, and purchases goods and services. In all these activities, scientific knowledge, the ability to evaluate claims scientifically, and trust 
in the scientific process can be beneficial- to the individual and his or her community. Thus, the role of the science educatorto develop courses and lessons that optimize our students' knowledge, skills, and trust in the process of science-is clear. We hope the work we describe can be useful to our colleagues as they develop these courses.

\section{ACKNOWLEDGMENTS}

We are grateful to Sadie Hebert for assistance with data collection; in addition, Sadie, Cissy Ballen, Abdi Warfa, and two anonymous reviewers provided helpful comments on an early draft of the article. This work was supported in part by a National Science Foundation IUSE grant (Integrated Science Education for Discovery in Introductory Biology, Proposal number 1432414), awarded to R.W., S.C., and Catherine Kirkpatrick, Department of Biology Teaching and Learning, University of Minnesota.

\section{REFERENCES}

Abraham, J. K., Perez, K. E., Downey, N., Herron, J. C., \& Meir, E. (2012). Short lesson plan associated with increased acceptance of evolutionary theory and potential change in three alternate conceptions of macroevolution in undergraduate students. CBE-Life Sciences Education, 11(2), 152164.

Alarcon, G. M., \& Edwards, J. M. (2012). Ability and motivation: Assessing individual factors that contribute to university retention. British Journal of Educational Psychology, 105(1), 129-137.

Allen-Ramdial, S. A. A., \& Campbell, A. G. (2014). Reimagining the pipeline: Advancing STEM diversity, persistence, and success. BioScience, 64(7), $612-618$.

Allum, N., Sturgis, P., Tabourazi, D., \& Brunton-Smith, I. (2008). Science knowledge and attitudes across cultures: A meta-analysis. Public Understanding of Science, 17(1), 35-54

American Association for the Advancement of Science. (2011). Vision and Change in Undergraduate Biology Education: A Call to Action. Washington, DC.

Armbruster, P., Patel, M., Johnson, E., \& Weiss, M. (2009). Active learning and student-centered pedagogy improve student attitudes and performance in introductory biology. CBE-Life Sciences Education, 8, 203-213.

Arwood, L. (2004). Teaching cell biology to nonscience majors through forensics, or how to design a killer course. Cell Biology Education, 3(2), 131-138. doi:10.1187/cbe.03-12-0023

Bangera, G., \& Brownell, S. E. (2014). Course-based undergraduate research experiences can make scientific research more inclusive. CBE-Life Sciences Education, 13(4), 602-606

Barnes, M. E., \& Brownell, S. E. (2016). Practices and perspectives of college instructors on addressing religious beliefs when teaching evolution. CBE-Life Sciences Education, 15(2), ar18. doi.10.1187/cbe.15-11-0243

Barnes, M. E., Elser, J., \& Brownell, S. E. (2017). Impact of a short evolution module on students' perceived conflict between religion and evolution. American Biology Teacher, 79(2), 104-111.

Busch, H. C. (2010). Using environmental science as a motivational tool to teach physics to non-science majors. Physics Teacher, 48(9), 578.

Carlone, H. B., \& Johnson, A. (2007). Understanding the science experiences of successful women of color: Science identity as an analytic lens Journal of Research in Science Teaching, 44(8), 1187-1218.

Cole, S. (2012). The Development of Science Identity: An Evaluation of Youth Development Programs at the Museum of Science and Industry, Chicago (Dissertations Paper 339). Retrieved July 14, 2017, from http://ecommons luc.edu/luc_diss/339

Connell, G. L., Donovan, D. A., \& Chambers, T. G. (2016). Increasing the use of student-centered pedagogies from moderate to high improves student learning and attitudes about biology. CBE-Life Sciences Education, 15(1), ar3.
Cook, M., \& Mulvihill, T. M. (2008). Examining US college students' attitudes towards science: Learning from non-science majors. Educational Research Review, 3(January), 38-47

Cordero, E. C., Todd, A. M., \& Abellera, D. (2008). Climate change education and the ecological footprint. Bulletin of the American Meteorological Society, 89(6), 865-872

Cotner, S., Ballen, C., Brooks, D. C., \& Moore, R. (2011). Instructor gender and student confidence in the sciences: A need for more role models? Journal of College Science Teaching, 40(5), 96-101.

Cotner, S., Brooks, D. C., \& Moore, R. (2010). Is the age of the earth one of our "sorest troubles"? Students' perceptions about deep time affect their acceptance of evolutionary theory. Evolution (NY), 64(3), 858-864.

Cotner, S., \& Gallup, G. G. Jr. (2011). Introductory biology labs ... They just aren't sexy enough! Bioscience Education, 18(1), 1-11.

Cotner, S., Loper, J., Walker, J. D., \& Brooks, D. C. (2013). It's not you, it's the room-Are the high-tech, active learning classrooms worth it? Journal of College Science Teaching, 42, 82-88.

Ding, D., Maibach, E. W., Zhao, X., Roser-Renouf, C., \& Leiserowitz, A. (2011) Support for climate policy and societal action are linked to perceptions about scientific agreement. Nature Climate Change, 1(9), 462-466. http://dx.doi.org/10.1038/nclimate1295

Eccles, J. S., Arberton, A., Buchanan, C. M., Jacobs, J., Flanagan, C., Harold, R ... Wigfield, A. (1993). School and family effects on the ontogeny of children's interests, self-perceptions, and activity choices. In Jacobs, J. (Ed.), Nebraska symposium on motivation: Developmental perspectives on motivation (Vol. 40, pp. 145-208). Lincoln: University of Nebraska Press.

Fenollar, P., Román, S., \& Cuestas, P. J. (2007). University students' academic performance: An integrative conceptual framework and empirical analysis. British Psychological Society, 77, 873-891. doi:10.1348/00070990 $7 X 189118$

Freeman, S., Eddy, S. L., McDonough, M., Smith, M. K., Okoroafor, N., Jordt, H., \& Wenderoth, M. P. (2014). Active learning increases student performance in science, engineering, and mathematics. Proceedings of the National Academy of Sciences USA, 111(23), 8410-8415. doi:10.1073/ pnas.1319030111

Gee, J. P. (2000). Identity as an analytic lens for research in education Review of Research in Education, 25, 99-125. doi:10.3102/009173 2X025001099

Gibson, J. P., \& Hoefnagels, M. H. (2015). Correlations between tree thinking and acceptance of evolution in introductory biology students. Evolution: Education and Outreach, 8(1), 15. http://dx.doi.org/10.1186/s12052-015 $-0042-7$

Glynn, S. M., Brickman, P., Armstrong, N., \& Taasoobshirazi, G. (2011). Science motivation questionnaire II: Validation with science majors and nonscience majors. Journal of Research in Science Teaching, 48(10), 1159-1176.

Guang, J., \& Bierma, T. (2013). STEM for non-STEM majors: Enhancing science literacy in large classes. Journal of College Science Teaching, 42(6), 20-26.

Haak, D. C., HilleRisLambers, J., Pitre, E., \& Freeman, S. (2011). Increased structure and active learning reduce the achievement gap in introductory biology. Science, 332(6034), 1213-1216. doi:10.1126/science.1204820

Hobson, A. (2001). Teaching relevant science for scientific literacy. Journal of College Science Teaching, 30(4), 238-243

Kahan, D. (2010). Fixing the communications failure. Nature, 463(7279) 296-297.

Kahan, D. M. (2012). Cultural cognition as a conception of the cultural theory of risk. In Roeser, S., Hillerbrand, R., Sandin, P., \& Peterson, M. (Eds.), Handbook of risk theory: Epistemology, decision theory, ethics, and social implications of risk (Vol. 1). Springer Science \& Business Media.

Kahan, D. M. (2013). A risky science communication environment for vaccines. Science, 342(6154), 53-54. Retrieved July 14, 2017, from www .ncbi.nlm.nih.gov/pubmed/24092722

Knight, J. K., \& Smith, M. K. (2010). Different but equal? How nonmajors and majors approach and learn genetics. CBE-Life Sciences Education, 9(1), 34-44.

Kolb, A. Y., \& Kolb, D. A. (2005). Learning styles and learning spaces: Enhancing experiential learning in higher education. Academy of Management LearningandEducation, 4(2),193-212. doi:10.5465/AMLE.2005.17268566

Lopatto, D. (2004). Survey of Undergraduate Research Experiences (SURE): First findings. Cell Biology Education, 3(4), 270-277. 
Luckie, D. B., Aubry, J. R., Marengo, B. J., Rivkin, A. M., Foos, L. A., \& Maleszewski, J. J. (2012). Less teaching, more learning: 10-yr study supports increasing student learning through less coverage and more inquiry. Advances in Physiology Education, 36(4), 325-235. doi:10.1152/advan 00017.2012

Luckie, D. B., Maleszewski, J. J., Loznak, S. D., \& Krha, M. (2004). Infusion of collaborative inquiry throughout a biology curriculum increases student learning: A four-year study of "teams and streams." Advances in Physiology Education, 28(1-4), 199-209.

Lundeberg, M. A., Fox, P. W., \& LeCount, J. (1992). Highly Confident, but Wrong: Gender Differences and Similarities in Confidence Judgments. Paper presented at the AERA (San Francisco, CA).

Manwaring, K. F., Jensen, J. L., Gill, R. A., \& Bybee, S. M. (2015). Influencing highly religious undergraduate perceptions of evolution: Mormons as a case study. Evolution: Education and Outreach, 8(1), 23. doi: http://dx doi.org/10.1186/s12052-015-0051-6

McCaffrey, M. S., \& Buhr, S. M. (2009). Clarifying climate confusion: Addressing systemic holes, cognitive gaps, and misconceptions through climate literacy. Physical Geography, 29, 512-528. doi:10.2747/0272-3646.29.6.512

McCright, A. M., \& Dunlap, R. E. (2011). Cool dudes: The denial of climate change among conservative white males in the United States. Global Environmental Change, 21(4), 1163-1172.

Medina, S. R., Ortlieb, E., \& Metoyer, S. (2014). Life science literacy of an undergraduate population. American Biology Teacher, 76(1), 34-41.

Miller, J. D. (2004). Public understanding of, and attitudes toward, scientific research: What we know and what we need to know. Public Understanding of Science, 13(3), 273-294.

Miller, J. D., Scott, E. C., \& Okamoto, S. (2006). Science communication. Public acceptance of evolution. Science, 313(5788), 765-766.

Moog, R. S., Creegan, F. J., Hanson, D. M., Spencer, J. N., \& Straumanis, A. R. (2006). Process-oriented guided inquiry learning: POGIL and the POGIL project. Metropolitan Universities, 17(4), 41-52.

Moore, R., Brooks, D. C., \& Cotner, S. (2011). The relation of high school biology courses \& students' religious beliefs to college students' knowledge of evolution. American Biology Teacher, 73(4), 222-226.

National Academy of Science, National Academy of Engineering, and Institute of Medicine. (2011). Expanding Underrepresented Minority Participation. Public Policy, doi:10.17226/12984

National Science Foundation, National Center for Science and Engineering Statistics. (2015). Women, Minorities, and Persons with Disabilities in Science and Engineering: 2015 Digest (Special Report NSF 15-311) [Internet]. Arlington, VA. Retrieved July 14, 2017, from www.nsf.gov/statistics/ wmpd

Nissen, J. M. (2016). Gender, experience, and self-efficacy in introductory physics. Physical Review Physics Education Research, 12(2), 20105

Nissen, J. M., \& Shemwell, J. T. (2016). Gender, experience, and self-efficacy in introductory physics. Physical Review Physics Education Research, 12, 20105.

Noble, J., \& Sawyer, R. (2002). Predicting Different Levels of Academic Success in College Using High School GPA and ACT Composite Score (ACT Research Report Series, 2002-4. 26) www.act.org/research/researchers/ reports/pdf/ACT_RR2002-4.pdf

O'Brien, D. T., Wilson, D. S., \& Hawley, P. H. (2009). "Evolution for everyone" A course that expands evolutionary theory beyond the biological sciences. Evolution Education Outreach, 2(3), 445-457. http://link.springer com/10.1007/s12052-009-0161-0
O'Keefe, P., Kerr, S., Johnson, V. K., Gans, S. E., Krumrine, J., \& Tinto, V. (1993) Leaving college: Rethinking the causes and cures of student attrition. College Student Journal, 45(4), 195-199. http://rer.sagepub.com/cgi/ doi/10.3102/00346543045001089\nhttp://connection.ebscohost.com/c/ articles/93813989/sense-belonging-improving-student-retention

Pajares, F. (1996). Self-efficacy beliefs in academic settings. Review of Educational Research, 66(4), 543-578.

Partin, M. L., Underwood, E. M., \& Worch, E. A. (1998). Factors related to college students' understanding of the nature of science: Comparison of science majors and nonscience majors. Journal of College Science Teaching, 42(6), 89-100.

Paz-y-Miño, C. G., \& Espinosa, A. (2009). Assessment of biology majors' versus nonmajors' views on evolution, creationism, and intelligent design. Evolution Education Outreach, 2(1), 75-83.

Pintrich, P. R., Smith, D. A. F., Garcian, T., \& McKeachie, W. J. (1991). A manual for the use of the Motivated Strategies for Learning Questionnaire (MSLQ). Ann Arbor, MI: National Center for Research to Improve Postsecondary Teaching and Learning.

Prince, M. (2004). Does active learning work? A review of the research. Journal of Engineering Education, 93(3), 223-231.

Rissler, L. J., Duncan, S. I., \& Caruso, N. M. (2014). The relative importance of religion and education on university students' views of evolution in the Deep South and state science standards across the United States. Evolution Education Outreach, 7(24), 1-17. www.evolution-outreach.com/ content/7/1/24

Sanz-Menendez, L., Van Ryzin, G. G., \& Del Pino, E. (2014). Citizens' support for government spending on science and technology. Science Public Policy, 41(5), 611-624.

Schauer, A., Cotner, S., \& Moore, R. (2014). Teaching evolution to students with compromised backgrounds and lack of confidence about evolution-is it possible?American Biology Teacher, 76(2), 93-98.

Seymour, E., Hunter, A. B., Laursen, S. L., \& Deantoni, T. (2004). Establishing the benefits of research experiences for undergraduates in the sciences: First findings from a three-year study. Science Education, 88(4), 493534.

Smith, W. S., Gould, S. M., \& Jones, J. A. (2004). Starting the semester at odds. Journal of College Science Teaching, 34(3), 44

Sundberg, M. D., \& Dini, M. L. (1993). Science majors vs nonmajors: Is there a difference? Journal of College Science Teaching, 23, 299-304.

Svihla, V., \& Linn, M. C. (2012). A design-based approach to fostering understanding of global climate change. International Journal of Science Education, 34(5), 651-676.

Terenzini, P. T., \& Pascarella, E. T. (1980). Toward the validation of Tinto's model of college student attrition: A review of recent studies. Research in Higher Education, 12(3), 271-282.

Tinto, V. (1987). Leaving College: Rethinking the Causes and Cures of Student Attrition. Chicago: University of Chicago Press.

Walker, J. D., Cotner, S. H., Baepler, P. M., \& Decker, M. D. (2008). A delicate balance: Integrating active learning into a large lecture course. CBE-Life Sciences Education, 7(4), 361-367.

Wilson, K., Low, D., Verdon, M., \& Verdon, A. (2016). Differences in gender performance on competitive physics selection tests. Physical Review Physics Education Research, 12(2), 20111. doi:10.1103/PhysRevPhysEducRes 12.020111

Wright, R., \& Klymkowsky, M. (2005). Feature points of view: Content versus process: Is this a fair choice? Cell Biology Education, 4, 189-198. 